\title{
Global History
}




\section{Journal of Global History}

\section{Chief Editor}

Professor Ewout Frankema

Wageningen University, The Netherlands

E-mail:jgh@wur.nl

\section{Co-Editors}

Dr Gagan Sood

London School of Economics and

Political Science, UK

E-mail:g.sood1@lse.ac.uk

Dr Heidi Tworek

University of British Columbia, Canada

E-mail: heidi.tworek@ubc.ca

\section{Editorial Board}

Professor Ahmed Ibrahim Abushouk

Qatar University, Qatar

Professor Gareth Austin

University of Cambridge, UK

Professor Maxine Berg

Warwick University, UK

\section{Dr John Chalcraft}

London School of Economics and

Political Science, UK

\section{Professor Ruma Chopra}

San Jose University, USA

Professor William Gervase Clarence-Smith SOAS, University of London, UK

Professor Rohan D'Souza

Kyoto University, Japan

Professor Mamadou Fall

UCAD, Dakar, Senegal
Professor Felipe Fernández-Armesto

University of Notre Dame, USA

Professor Ulrike Freitag

Free University of Berlin,

Germany

Professor Olivier Grenouilleau

Centre Roland Mousnier, Paris-IV

Sorbonne, France

Professor Pamila Gupta

University of Witwatersrand,

Johannesburg, South Africa

Professor Marnie Hughes-Warrington

Australian National University,

Australia

Professor Joseph E. Inikori

University of Rochester, USA

Professor Michael C. Low

Iowa State University,

USA

\section{Professor Leo Lucassen}

International Institute of Social History,

The Netherlands

\section{Professor Mary Jo Maynes}

University of Minnesota,

USA

Dr Anna-Maria Misra

University of Oxford, UK

Professor Ayodeji Olukoju

University of Lagos, Nigeria
Professor Olivette Otele

University of Bristol, UK

Dr Ronald C. Po

London School of Economics and Political Science, UK

\section{Professor Kenneth Pomeranz}

University of Chicago

Professor Patricia Seed

University of California,

Irvine, USA

Professor Tansen Sen

NYU Shanghai, China

Professor Akita Shigeru

Osaka University, Japan

Professor Kaoru Sugihara

Research Institute for Humanity and

Nature (RIHN), Japan

Professor Barbara Watson Andya

University of Hawai'i, USA

Professor Merry Wiesner-Hanks

University of Wisconsin Milwaukee, USA

Professor Nurfadzilah Yahaya

National University of Singapore,

Singapore

\section{Managing Editor}

Dannielle Shaw

Journal of Global History

E-mail:D.Shaw@uea.ac.uk

Website: cambridge.org/jgh 